\title{
Surgical resection of localized hepatocellular carcinoma: patient selection and special consideration
}

\section{Ka Wing Ma \\ Tan To Cheung}

Department of Surgery, Queen Mary Hospital, The University of Hong Kong, Pok Fu Lam, Hong Kong
Correspondence: Tan To Cheung Department of Surgery, Queen Mary Hospital, 102 Pokfulam Road, Hong Kong Email tantocheung@hotmail.com
This article was published in the following Dove Press journal:

Journal of Hepatocellular Carcinoma

28 December 2016

Number of times this article has been viewed

\begin{abstract}
Localized hepatocellular carcinoma (HCC) refers to a solitary or few tumors located within either the left or right hemiliver without evidence of bilobar or extrahepatic spread. This term encompasses a heterogeneous morphology with no regard to stage of prognosis of the disease. Surgical resection remains the mainstay of curative treatment for the localized HCC. Various biochemical and radiological tests constitute an indispensible part of preoperative assessment. Emergence of laparoscopic hepatectomy has brought liver resection into a new era. Improved understanding of the pathophysiology of HCC allows more aggressive surgical resection without compromising outcomes. New insights into the management of special situations, such as ruptured HCC, pyogenic transformation of HCC, and HCC with portal vein tumor thrombus, rekindle the hopes of curative resection in these terminal events. Amalgamating salvage liver transplantation into the surgical management of resectable $\mathrm{HCC}$ has revolutionized the treatment paradigm of this deadly disease.
\end{abstract}

Keyword: hepatocellular carcinoma, hepatectomy, future liver remnant, transarterial chemoembolization (TACE), transarterial radioembolization (TARE)

\section{Introduction}

Hepatocellular carcinoma (HCC) is the most common primary hepatic malignancy. It is the fifth most common cancer and is ranked the third most common cause of cancer-related mortality around the world, leading to over 1 million deaths every year. ${ }^{1,2}$ Majority of the patients present with unresectable disease due to the presence of extrahepatic spread, insufficient future liver remnant (FLR), poor liver function, performance status, etc. Survival of this group of patients are counted in months despite the development of various forms of palliative treatment such as transarterial chemoembolization (TACE), ${ }^{3-5}$ transarterial radioembolization, ${ }^{6}$ and vascular endothelial growth factor receptor antagonist, also known as sorafenib. ${ }^{7,8}$ Localized HCC does not necessarily infer straightforward management; huge tumor, strategic tumor location, major vasculobiliary invasion, rupture of HCC, and pyogenic transformation are situations that complicate the picture. For the minority of fortunate patients who have early disease, liver transplantation (LT) offers the "best chance of cure", with 5-year survival ranging from $70 \%$ to $90 \%$ depending on different selection criteria (Table 1). ${ }^{9-15}$ However, due to a scarcity of liver graft and stringent selection criteria, only a small fraction of these patients can benefit from LT, with almost $90 \%$ of them having to undergo either ablative therapy or partial hepatectomy. Despite the fact that radiofrequency and microwave ablation have been proven to be as effective 
Table I HCC survival after liver transplantation from different series

\begin{tabular}{|c|c|c|c|c|}
\hline Criteria & $\begin{array}{l}\text { Tumor } \\
\text { size }\end{array}$ & $\begin{array}{l}\text { Tumor } \\
\text { number }\end{array}$ & $\begin{array}{l}\text { Additional } \\
\text { restriction }\end{array}$ & $\begin{array}{l}\text { Overall } \\
5 \text {-year } \\
\text { survival (\%) }\end{array}$ \\
\hline $\mathrm{UCSF}^{10}$ & $\begin{array}{l}<6.5 \mathrm{~cm} \\
<4.5 \mathrm{~cm} \\
\text { Total }<8 \mathrm{~cm}\end{array}$ & $\begin{array}{l}\text { Solitary } \\
3 \text { or less }\end{array}$ & - & 75.2 \\
\hline $\begin{array}{l}\text { University } \\
\text { of Tokyo" }\end{array}$ & $\leq 5 \mathrm{~cm}$ & 5 or less & - & 75 \\
\hline Chang Guan & $6.5 \mathrm{~cm}$ & I & - & 90 \\
\hline University'2 & $4.5 \mathrm{~cm}$ & 3 or less & & \\
\hline Asan ${ }^{13}$ & $\leq 5 \mathrm{~cm}$ & 6 or less & - & 82 \\
\hline Up-to-7 ${ }^{14}$ & $\leq 7$ & 7 or less & $\begin{array}{l}\text { Numerical sum } \\
\text { of tumor size } \\
\text { and number } \\
\text { must be }<7\end{array}$ & 71.2 \\
\hline Hangzhou' ${ }^{15}$ & $\begin{array}{l}\text { Total size } \\
\leq 8 \mathrm{~cm}\end{array}$ & No limit & $\begin{array}{l}\text { For total tumor } \\
\text { size }>8 \mathrm{~cm} \text {, } \\
\text { histological } \\
\text { grade must } \\
\text { be I or II and } \\
\text { AFP must be } \\
\leq 400 \mathrm{ng} / \mathrm{L}\end{array}$ & 72 \\
\hline
\end{tabular}

Abbreviation: AFP, alpha-fetoprotein; HCC, hepatocellular carcinoma; UCSF, University of California, San Francisco.

as resection for small-sized $\mathrm{HCC},{ }^{16-19}$ their applicability is limited by a number of constraints, such as tumor size (too big would risk incomplete ablation), location (too subscapular or too deep-seated), and vicinity to vascular (fear of heat sink effect), biliary, and hollow organ structure (possible collateral damage). At present, liver resection remains the mainstay of curative measure due to its availability, flexibility, and inherent efficacy. The overall 5-year survival of $\mathrm{HCC}$ patients after resection is $>50 \%$ in most series, and this number can be $>70 \%$ for early disease..$^{20-22}$ In this article, we will go through the technical advances in surgical resection of HCC, stratification and selection of patients via different investigation modality, and how to deal with special circumstances in patients with localized HCC.

\section{Surgical resection for $\mathrm{HCC}$}

Liver resection was once considered as an ultra-high-risk procedure, and usually resulted in massive blood loss, high morbidity, and mortality. ${ }^{23}$ Until the $1980 \mathrm{~s}$, the mortality rate of liver resection was still $\sim 10 \%$ in many centers. ${ }^{24,25}$ Over the last few decades, a multitude of perioperative and technical advances have emerged, changing the landscape in the field of liver resection. Liver resection can be classified into nonanatomical and anatomical resection. The former essentially means excision of $\mathrm{HCC}$ with a rim of normal liver tissue regardless of the location of the tumor; anatomical resection refers to resection of a specific part of the liver according to corresponding pedicle supply and biliary drainage. Because most HCC recurrences are intrahepatic and it has been postulated that cancer cells spread by microscopic invasion and dissemination along portal pedicle, ${ }^{26-28}$ liver resection following its corresponding portal pedicle should theoretically maximize oncological clearance. ${ }^{29-32}$ However, this oncological benefit is not demonstrated in some other studies. ${ }^{33-38}$ The reason behind the discrepancy was that, a majority of the nonanatomical resections were performed for patients with cirrhosis with the hope of conserving the more functional liver remnant, and a cirrhotic liver is more prone to tumor recurrence due to "field change" and has a worse prognosis when compared to the noncirrhotic one; hence, it is falsely perceived as the cause of inferior oncological outcome. Further well-designed randomized controlled trial is needed to properly address this issue.

Besides the controversy of anatomical and nonanatomical resection, the surgical approach of hepatectomy has been a topic for debate. Since the first laparoscopic hepatectomy (LH) performed by Gagner in 1992, ${ }^{39}$ there has been growing enthusiasm to pursue this challenging operative approach from all around the world. Initial indication of LH was limited to benign diseases of the liver. Thanks to the accumulation of experience and reports of encouraging results, the indication of LH has been extended to various types of hepatic malignancies, chiefly colorectal liver metastasis and HCC. ${ }^{40-43}$

The main concerns about laparoscopic hepatectomy were oncological clearance and safety issues of this approach. However, apart from the inherent benefit of laparoscopic surgery, such as shorter hospital stay, ${ }^{44-47}$ operation time, ${ }^{46,48,49}$ less analgesic requirement, ${ }^{45}$ and early resumption of oral intake, ${ }^{45}$ it has been demonstrated that $\mathrm{LH}$ is associated with good safety profile, as evidenced by less blood loss, ${ }^{46,48-50}$ and postoperative morbidities and mortality. ${ }^{46,47,49,51}$ From the perspective of oncological efficacy, a meta-analysis comprising 244 patients with open hepatectomy and 165 patients with LH for liver cancers found that there were no significant differences in tumor-free resection margin, disease-free and overall survival. ${ }^{52}$ Subsequent studies confirmed these advantages in the context of treating HCC. ${ }^{53-55}$ Despite the fact that the laparoscopic approach has been recommended as the standard of care for minor wedge resection and left lateral sectionectomy, ${ }^{56}$ its application in major liver resection was still considered as "in exploration phase" due to the complexity of the procedure and the steep learning curve. ${ }^{56,57}$ With the constantly 
emerging laparoscopic devices and effective hemostatic products, ${ }^{58}$ hurdles in laparoscopic major hepatectomy would be overcome in the near future.

\section{Patient selection}

As a rule of thumb, careful patient selection is always the key to treatment success regardless of the type and approach of liver resection used. Treatment options for HCC are largely inferred by patient, livers, and tumor factors at presentation and these factors form the backbone of a number of welladopted treatment algorithms (Table 2). ${ }^{59-63}$ The association between general health condition and prognosis of HCC had been well documented..$^{22,59,64-67}$ In general, patients with poor cardiopulmonary function, limited life expectancy, or poor quality of life (i.e., bedridden and noncommunicable) due to underlying medical comorbidities are not a surgical candidate. Liver factors are traditionally assessed by the Child-Pugh score. ${ }^{68,69}$ This score was originally used to predict the survival of patients with portal hypertension after portosystemic shunt surgery and subsequently was applied to predict liver-related mortality of cirrhotic patients. Lack of discrimination within the same grade and involvement of subjective clinical parameters limit its role in preoperative assessment. Objective biochemical, radiological, and metabolic assessments have become the standard practice in many centers. Indocyanine green (ICG) is a metabolically inert dye. It does not get metabolized or degraded in blood, is solely and actively excreted by hepatocytes, and is not reabsorbed via the enterohepatic pathway; hence, it is an ideal marker for liver function assessment. ${ }^{70-74}$ ICG is injected at a dosage $0.5 \mathrm{mg} / \mathrm{kg}$ intravenously; serum retention of ICG
$>15 \%$ at 15 minutes is generally considered inadequate ${ }^{75}$ although it has been reported that the safety cutoff can be as high as $20 \%$ for a Child-Pugh A patient. ${ }^{76}$ The ICG clearance test has become a routine preoperative liver function assessment in many centers around the world, and its serum level can be checked with pulse spectrophotometry, which is faster and not influenced by potential human error during serial venous blood sampling. ${ }^{77,78}$ In addition, the ICG disappearance rate and intraoperative ICG measurement for the FLR were found to have prognostic implication in liver resection and will continue to be a topic of research in the future. ${ }^{71,79,80}$

Apart from biochemical assessment with ICG, volumetric assessment of the FLR constitutes an indispensible part of the preoperative work-up. With the development of helical, multi-detector, thin-slicing CT technology, high-quality images can be obtained in just one breath holding time, and subsequent FLR volume calculation can be done by either an automated or a manual process with good accuracy. ${ }^{81,82}$ The resultant volume is then divided by total liver volume (TLV), which is obtained either by CT volumetry (after subtraction of tumor volume) or deduced from various formulas. ${ }^{83-85}$ The ratio of FLR volume to TLV of $25 \%-30 \%$ for noncirrhotic patients ${ }^{86-88}$ and up to $40 \%$ for cirrhotic patients ${ }^{89}$ are considered safe for hepatectomy. In case of situations like the presence of steatosis, fibrosis, and cirrhosis, where the liver function might not correlate well with the liver volume, ${ }^{90}$ Technitium-99 mebrofenin or galactosyl human serum albumin scintigraphy can be used for metabolic assessment of the whole or partial liver function. ${ }^{91-93}$

Table 2 Commonly referred treatment guidelines for HCC

\begin{tabular}{|c|c|c|c|c|}
\hline Guidelines & Parameters & Concept of vascular invasion & Tumor staging & Resectability \\
\hline $\mathrm{BCLC}^{59}$ & $\begin{array}{l}\text { Performance status } \\
\text { Liver function } \\
\text { Tumor status }\end{array}$ & $\begin{array}{l}\text { Invasion of PV branches signifies } \\
\text { advance disease }\end{array}$ & $\begin{array}{l}\text { Classified as very early, early, } \\
\text { intermediate, advance and } \\
\text { terminal }\end{array}$ & $\begin{array}{l}\text { Solitary HCC or }<3 \text { tumor } \\
<3 \mathrm{~cm}\end{array}$ \\
\hline $\mathrm{HKLC}^{60}$ & $\begin{array}{l}\text { Performance status } \\
\text { Liver function } \\
\text { Tumor status }\end{array}$ & Main PV or IVC invasion & Early, intermediate or late & $\begin{array}{l}\text { Early tumor in Child A/B } \\
\text { cirrhosis } \\
\text { Intermediate in Child A } \\
\text { cirrhosis }\end{array}$ \\
\hline $\mathrm{JSH}^{61}$ & $\begin{array}{l}\text { Liver function } \\
\text { Presence of vascular } \\
\text { invasion } \\
\text { Prensece of metastasis }\end{array}$ & $\mathrm{PV}$ invasion classified into $\mathrm{VPl}-4$ & $\begin{array}{l}\text { According to TNM stage of } \\
\text { LCSGJ }\end{array}$ & Any resectable $\mathrm{HCC}$ \\
\hline APASAL $^{62}$ & $\begin{array}{l}\text { Liver function } \\
\text { Presence of vascular } \\
\text { invasion } \\
\text { Prensece of metastasis }\end{array}$ & $\begin{array}{l}\text { Involvement of main PV or IVC } \\
\text { branches }\end{array}$ & $\begin{array}{l}3 \text { categories: Resectable, within } \\
\text { Milan/unresectable within Milan } \\
\text { and unresectable outside Milan } \\
\text { criteria }\end{array}$ & $\begin{array}{l}\text { HCC with invasion to sectorial } \\
\text { branches of PV still be } \\
\text { considered resectable }\end{array}$ \\
\hline
\end{tabular}

Notes: PV tumor invasion was classified into: $V_{p} 0$, no PV invasion; $V_{p} I$, thrombus beyond 2nd order PV branch; $V_{p} 2$, thrombus at 2nd order branch; $V_{p} 3$, thrombus at Ist order branch; $V_{P} 4$, thrombus at main PV or involved contralateral PV.

Abbreviations: APASL, Asian Pacific Association for the Study of the Liver; BCLC, Barcelona Clinic for Liver Cancer; HCC, hepatocelluar carcinoma; HKLC, Hong Kong Liver Cancer; JSH, Japan Society of Hepatology; LCSG], Liver Cancer Study Group of Japan; PV, portal vein; IVC, inferior vena cava. 
The indication and patient selection principle should hold true for both open and LH; nonetheless, the decision of whether a particular HCC is suitable for laparoscopic resection involves a number of considerations. A 10-level difficulty index introduced by the Keio University group ${ }^{94}$ provides a comprehensive stratification of HCC for pure LH. This score takes tumor size, tumor location, extent of resection, degree of cirrhosis, and proximity to the major vessel into account and serves as a useful guide for both patient selection and surgeon selection, i.e., operation with high difficulty index should only be performed by experienced laparoscopic surgeon while those with low difficulty index are suitable cases for beginners in LH. For patients with large posteriorly situated lesion with high difficulty score, use of a hand-assisted or hybrid laparoscopic approach had been suggested to reduce the patient risk and need for conversion. ${ }^{49,95-97}$ In case the operating surgeon perceives that the laparoscopic approach would compromise patient safety or oncological outcome, conversion to open hepatectomy is indicated.

\section{Special circumstances Insufficient FLR}

Since the development of portal vein embolization (PVE) by Makuuchi, ${ }^{98}$ insufficient FLR is no longer regarded as an absolute contraindication for major hepatectomy. This technique was originally described for the use in treating hilar cholangiocarcinoma, ${ }^{99}$ and this application had been extended to many other primary and secondary hepatic malignancies. In the context of HCC, this technique is even more relevant as HCC often develops in the background of shrunken cirrhotic liver. Studies showed that the 5-year survival after resection for patients who had PVE before ranged from $50 \%$ to $70 \%$, and this is comparable to HCC resection without prior PVE. ${ }^{100-103}$ Besides promoting hypertrophy of FLR, this technique also acts as a selection tool to screen out patients who are unlikely to survive a major hepatectomy due to poor regenerative potential of the liver parenchyma and intolerance to portal hypertension after the procedure. However, PVE had been criticized of not being able to introduce sufficient FLR hypertrophy and possibility of disease progression during the 4-week hypertrophy time. It has been reported that due to increased arterial supply to the tumor-bearing liver during the post-PVE period, the tumor growth rate accelerates due to the hypervascularized nature of $\mathrm{HCC},{ }^{104}$ and the patient dropout rate can be up to $20 \%-25 \%$. With the introduction of the new technique of associating liver partition and portal vein ligation for staged hepatectomy (ALPPS), problems of PVE seem to have been well addressed with faster and more FLR hypertrophy. The first report of ALPPS from Schnitzbauer found that this procedure induced liver hypertrophy of $75 \%$ in only 9 days. ${ }^{105}$ However, in return for the improved resectability, ALPPS was noted to be associated with higher morbidity, mortality, and higher early recurrence rate. ${ }^{106-108}$ Though early results of ALPPS were promising, these issues need to be clarified before this technique can gain further acceptance to become a standard of practice.

\section{Ruptured HCC}

Ruptured HCC is associated with poor prognosis and its incidence varies geographically, from $10 \%$ in some Asian countries ${ }^{109,110}$ to $<5 \%$ in the Western world. ${ }^{110}$ According to the tumor-node-metastasis staging, seventh edition, ${ }^{111}$ ruptured $\mathrm{HCC}$ was classified as $\mathrm{T}_{4}$ disease. While, some people considered it as a contraindication for curative surgery, the others reported that resectability of patients with ruptured HCC could be up to $12 \%-33 \% .^{110,112-114}$ We have recently analyzed the surgical outcomes of patients with ruptured HCC undergoing liver resection and found that the 1-, 3-, and 5 -year overall survivals were $66 \%, 37 \%$, and $22.3 \%$, respectively, which is statistically worse than nonruptured HCC $(83.3 \%, 64.8 \%$, and $53.4 \%$ respectively, $P<0.001$ ), but superior to those who received TACE or systemic therapy. ${ }^{61}$ Therefore, resection should be contemplated for patients who have ruptured HCC without overt evidence of dissemination.

\section{Portal vein tumor thrombus}

$\mathrm{HCC}$ has the tendency of invading the portal vein, which explains the high incidence of portal vein tumor thrombus (PVTT) of $\sim 40 \% .{ }^{114}$ The presence of PVTT in HCC patients signifies poor prognosis with median survival of only 2.7 months if left untreated. ${ }^{115}$ This tumor thrombus can propagate and lead to complete PV obstruction, causing torrential variceal hemorrhage. Treatment for PVTT remained limited, and its presence was usually considered a contraindication for resection and TACE. Resection is the only possible cure and is associated with an operative mortality of $0 \%-5.9 \%$ and the median survival ranged from 8.9 to 33 months. ${ }^{116-119}$ Surgical management of PVTT depends on the level of involvement. For peripherally located PVTT confined to the ipsilateral first-generation portal vein, hepatectomy is recommended. Treatment options for PVTT extending to or beyond portal vein bifurcation include en-bloc resection and thrombectomy. Although portal vein en-bloc resection seems to give a sense 
of better oncological clearance, majority of the literatures did not find a significant difference in survival benefit between the two. ${ }^{118,120-122}$ Preoperative TACE had been proposed and was able to achieve 5-year survival in $45 \%$ of selected patients. ${ }^{123}$ However, these encouraging results could not be repeated by others. ${ }^{121,123}$ Efficacy of some newer adjuvant therapies such as sorafenib ${ }^{7}$ and infusion of platinum-based chemotherapy via hepatic artery ${ }^{124}$ are areas for further exploration.

\section{$\mathrm{HCC}$ with bile duct tumor thrombus}

Bile duct tumor thrombus (BDTT) is an uncommon occurrence in the context of HCC. It happens in $0.53 \%-13 \%$ of the HCC patients. ${ }^{125-127}$ Prognosis of HCC with BDTT is worse than HCC without BDTT. ${ }^{128-130}$ This difference was thought to be related to a more aggressive tumor biology evidenced by higher proportion of coexisiting lymphovascular invasion in patients with BDTT. ${ }^{131}$ Preoperative drainage is occasionally required in case of severe cholestasis or cholangitis, and can be done by endoscopic retrograde cholangiopancreatography or percutaneous transhepatic biliary drainage. Tumor thrombus is easily retrievable with balloon used for stone extraction due to its necrotic and friable nature. Although Ueda classification ${ }^{132}$ could be used as a guide for calculating the extent of hepatectomy, our previous analysis ${ }^{131}$ suggested that radical hepatectomy with extrahepatic bile duct resection was associated with better outcome. A 5-year overall survival of 38.5\% with zero bile duct recurrence was achieved using this approach.

\section{HCC with abscess formation}

The reported incidence of de novo pyogenic transformation of $\mathrm{HCC}$ is $\sim 1 \%$. ${ }^{133}$ The manifestations of HCC complicated by liver abscess include pyrexia, right upper abdominal pain, right pleural effusion, and leukocytosis. Portal pyemia, ascending cholangitic sepsis, and hemotological inoculation of bacteria in a necrotic tumor are some postulated etiology. ${ }^{134,135}$ There has been no standardized management for this rare entity; upfront hepatectomy for HCC with abscess formation was not recommended due to the reported higher morbidity, mortality, and worse oncological outcomes. ${ }^{133}$ Early involvement of microbiologist and interventional radiologist is advisable; hepatectomy should be performed in a patient with sepsis under control and general conditions optimized so as to minimize the above-mentioned adverse outcomes.

\section{Surgical resection as a bridging therapy to LT}

LT has been the best curative treatment for HCC within certain criteria. The 5-year survival of HCC patients after
LT can be up to $90 \%$ in certain series. ${ }^{12}$ However, due to graft shortage and disease progression, a $43 \%$ dropout rate for HCC patients on a waiting list had been reported. ${ }^{136}$ The concept of salvage transplantation was introduced in 2000 by Majno et $\mathrm{al}^{137}$ in which they advocated that HCC patients should proceed with resection first whenever possible and embark on LT only when recurrence developed. This strategy would relieve tension in donor pool by postponing the time of LT and even reducing the number of LT, as some of the patients might not develop HCC recurrence after resection. While salvage LT had been recognized as an incorporated part of HCC management, ${ }^{138}$ opponents of the policy of salvage transplant worried that liver transplantation following previous hepatectomy might impair transplantability and increase the operative risk due to the presence of adhesion and distorted anatomy; compromised long-term survival of salvage transplant patients was also a concern. ${ }^{139}$ We had previously reported that there was no significant difference in long-term survival between HCC patients treated by upfront resection or primary LT, provided that the factor of microvascular invasion is adjusted, ${ }^{140}$ and when there is HCC recurrence, salvage LT gives the best 5-year model for endstage liver disease-adjusted survival in comparison to repeat resection and ablation. ${ }^{141}$ Therefore, localized HCC should be resected whenever possible, especially in the region of low organ donation rate. Salvage LT should be reserved for any unresectable HCC recurrence.

\section{Conclusion}

With the advances in various preoperative biochemical and radiological assessments, the safety profile of hepatectomy for HCC has drastically improved. Situations such as insufficient FLR and PVTT that were once considered not amendable to surgical resection have now become resectable. Increased understanding of special conditions like HCC rupture, abscess transformation, and the role of salvage LT allows better choice of treatment and improves long-term outcomes for $\mathrm{HCC}$ patients.

\section{Disclosure}

The authors report no conflicts of interest in this work.

\section{References}

1. El-Serag HB. Hepatocellular carcinoma: an epidemiologic view. JClin Gastroenterol. 2002;35(5):S72-S78.

2. Rossi L, Zoratto F, Papa A, Iodice F, Minozzi M, Frati L, Tomao S. Current approach in the treatment of hepatocellular carcinoma. World $J$ Gastrointest Oncol. 2010;2(9):348-359.

3. Lo CM, Ngan H, Tso WK, et al. Randomized controlled trial of transarterial lipiodol chemoembolization for unresectable hepatocellular carcinoma. Hepatology. 2002;35(5):1164-1171. 
4. Golfieri R, Giampalma E, Renzulli M, et al. Randomised controlled trial of doxorubicin-eluting beads vs conventional chemoembolisation for hepatocellular carcinoma. Br J Cancer. 2014;111(2):255-264.

5. Salem R, Lewandowski RJ, Mulcahy MF, et al. Radioembolization for hepatocellular carcinoma using Yttrium-90 microspheres: a comprehensive report of long-term outcomes. Gastroenterology. 2010;138(1):52-64.

6. Mazzaferro V, Sposito C, Bhoori S, et al. Yttrium-90 radioembolization for intermediate-advanced hepatocellular carcinoma: a phase 2 study. Hepatology. 2013;57(5):1826-1837.

7. Llovet JM, Ricci S, Mazzaferro V, et al. Sorafenib in advanced hepatocellular carcinoma. N Engl J Med. 2008;359(4):378-390.

8. Cheng AL, Kang YK, Chen Z, et al. Efficacy and safety of sorafenib in patients in the Asia-Pacific region with advanced hepatocellular carcinoma: a phase III randomised, double-blind, placebo-controlled trial. Lancet Oncol. 2009;10(1):25-34.

9. Mazzaferro V, Regalia E, Doci R, et al. Liver transplantation for the treatment of small hepatocellular carcinomas in patients with cirrhosis. N Engl J Med. 1996;334(11):693-699.

10. Yao FY, Ferrell L, Bass NM, et al. Liver transplantation for hepatocellular carcinoma: expansion of the tumor size limits does not adversely impact survival. Hepatology. 2001;33(6):1394-1403.

11. Sugawara Y, Tamura S, Makuuchi M. Living donor liver transplantation for hepatocellular carcinoma: Tokyo University series. Dig Dis. 2007;25(4):310-312.

12. Concejero A, Chen CL, Wang CC, et al. Living donor liver transplantation for hepatocellular carcinoma: a single-center experience in Taiwan. Transplantation. 2008;85(3):398-406.

13. Lee SG, Hwang S, Moon DB, et al. Expanded indication criteria of living donor liver transplantation for hepatocellular carcinoma at one large-volume center. Liver Transpl. 2008;14(7):935-945.

14. Mazzaferro V, Llovet JM, Miceli R, et al. Predicting survival after liver transplantation in patients with hepatocellular carcinoma beyond the Milan criteria: a retrospective, exploratory analysis. Lancet Oncol. 2009;10(1):35-43.

15. Zheng SS, Xu X, Wu J, et al. Liver transplantation for hepatocellular carcinoma: Hangzhou experiences. Transplantation. 2008;85(12): 1726-1732.

16. Chen MS, Li JQ, Zheng Y, et al. A prospective randomized trial comparing percutaneous local ablative therapy and partial hepatectomy for small hepatocellular carcinoma. Ann Surg. 2006;243(3):321-328.

17. Feng K, Yan J, Li X, et al. A randomized controlled trial of radiofrequency ablation and surgical resection in the treatment of small hepatocellular carcinoma. J Hepatol. 2012;57(4):794-802.

18. Livraghi T, Meloni F, Di Stasi M, Rolle E, Solbiati L, Tinelli C, Rossi S. Sustained complete response and complications rates after radiofrequency ablation of very early hepatocellular carcinoma in cirrhosis: is resection still the treatment of choice? Hepatology. 2008;47(1): 82-89.

19. Groeschl RT, Pilgrim CH, Hanna EM, et al. Microwave ablation for hepatic malignancies: a multiinstitutional analysis. Ann Surg. 2014;259(6):1195-1200.

20. Poon RT, Fan ST, Lo CM, Liu CL, Wong J. Long-term survival and pattern of recurrence after resection of small hepatocellular carcinoma in patients with preserved liver function: implications for a strategy of salvage transplantation. Ann Surg. 2002;235(3):373-382.

21. Llovet JM, Fuster J, Bruix J. Intention-to-treat analysis of surgical treatment for early hepatocellular carcinoma: resection versus transplantation. Hepatology. 1999;30(6):1434-1440.

22. Fan ST, Lo CM, Poon RT, et al. Continuous improvement of survival outcomes of resection of hepatocellular carcinoma: a 20-year experience. Ann Surg. 2011;253(4):745-758.

23. Foster JH, Berman MM. Solid liver tumors. Major Probl Clin Surg. 1977;22:1-342.

24. Fortner JG, MacLean BJ, Kim DK, et al. The seventies evolution in liver surgery for cancer. Cancer. 1981;47(9):2162-2166.

25. Thompson HH, Tompkins RK, Longmire WP Jr. Major hepatic resection: a 25-year experience. Ann Surg. 1983;197(4):375-388.
26. Cucchetti A, Zanello M, Cescon M, et al. Improved diagnostic imaging and interventional therapies prolong survival after resection for hepatocellular carcinoma in cirrhosis: the university of bologna experience over 10 years. Ann Surg Oncol. 2011;18(6):1630-1637.

27. Park JH, Koh KC, Choi MS, et al. Analysis of risk factors associated with early multinodular recurrences after hepatic resection for hepatocellular carcinoma. Am J Surg. 2006;192(1):29-33.

28. Vauthey JN, Lauwers GY, Esnaola NF, et al. Simplified staging for hepatocellular carcinoma. J Clin Oncol. 2002;20(6):1527-1536.

29. Yuki K, Hirohashi S, Sakamoto M, Kanai T, Shimosato Y. Growth and spread of hepatocellular carcinoma. A review of 240 consecutive autopsy cases. Cancer. 1990;66(10):2174-2179.

30. Eguchi S, Kanematsu T, Arii S, et al. Comparison of the outcomes between an anatomical subsegmentectomy and a non-anatomical minor hepatectomy for single hepatocellular carcinomas based on a Japanese nationwide survey. Surgery. 2008;143(4):469-475.

31. Wakai T,Shirai Y,Sakata J, Kaneko K, Cruz PV, Akazawa K, Hatakeyama K. Anatomic resection independently improves long-term survival in patients with T1-T2 hepatocellular carcinoma. Ann Surg Oncol. 2007;14(4):1356-1365.

32. Hasegawa K, Kokudo N, Imamura H, et al. Prognostic impact of anatomic resection for hepatocellular carcinoma. Ann Surg. 2005;242(2): 252-259.

33. Kaibori M, Matsui Y, Hijikawa T, Uchida Y, Kwon AH, Kamiyama Y. Comparison of limited and anatomic hepatic resection for hepatocellular carcinoma with hepatitis C. Surgery. 2006;139(3):385-394.

34. Kang CM, Choi GH, Kim DH, Choi SB, Kim KS, Choi JS, Lee WJ. Revisiting the role of nonanatomic resection of small $(<$ or $=4 \mathrm{~cm})$ and single hepatocellular carcinoma in patients with well-preserved liver function. J Surg Res. 2010;160(1):81-89

35. Tomimaru Y, Eguchi H, Marubashi S, et al. Equivalent outcomes after anatomical and non-anatomical resection of small hepatocellular carcinoma in patients with preserved liver function. Dig Dis Sci. 2012;57(7):1942-1948.

36. Marubashi S, Gotoh K, Akita H, et al. Anatomical versus non-anatomical resection for hepatocellular carcinoma. Br J Surg. 2015;102(7): 776-784.

37. Chen J, Huang K, Wu J, Zhu H, Shi Y, Wang Y, Zhao G. Survival after anatomic resection versus nonanatomic resection for hepatocellular carcinoma: a meta-analysis. Dig Dis Sci. 2011;56(6):1626-1633.

38. Zhou Y, Xu D, Wu L, Li B. Meta-analysis of anatomic resection versus nonanatomic resection for hepatocellular carcinoma. Langenbecks Arch Surg. 2011;396(7):1109-1117.

39. Gagner M, Rheault M, Dubuc J. Laparoscopic partial hepatectomy for liver tumor. Surg Endosc. 1992;6(2):97-98.

40. Tranchart H, Di Giuro G, Lainas P, Roudie J, Agostini H, Franco D, Dagher I. Laparoscopic resection for hepatocellular carcinoma: a matched-pair comparative study. Surg Endosc. 2010;24(5): 1170-1176.

41. Cheung TT, Poon RT, Yuen WK, et al. Outcome of laparoscopic versus open hepatectomy for colorectal liver metastases. ANZ J Surg. 2013;83(11):847-852.

42. Cheung TT, Ng KK, Poon RT, Chan SC, Lo CM, Fan ST. A case of laparoscopic hepatectomy for recurrent hepatocellular carcinoma. World J Gastroenterol. 2010;16(4):526-530.

43. Belli G, Fantini C, D’Agostino A, Cioffi L, Langella S, Russolillo N, Belli A. Laparoscopic versus open liver resection for hepatocellular carcinoma in patients with histologically proven cirrhosis: short- and middle-term results. Surg Endosc. 2007;21(11):2004-2011.

44. Buell JF, Cherqui D, Geller DA, et al. The international position on laparoscopic liver surgery: the Louisville Statement, 2008. Ann Surg. 2009;250(5):825-830.

45. Cai XJ, Yang J, Yu H, Liang X, Wang YF, Zhu ZY, Peng SY. Clinical study of laparoscopic versus open hepatectomy for malignant liver tumors. Surg Endosc. 2008;22(11):2350-2356.

46. Koffron AJ, Auffenberg G, Kung R, Abecassis M. Evaluation of 300 minimally invasive liver resections at a single institution: less is more. Ann Surg. 2007;246(3):385-392. 
47. Topal B, Fieuws S, Aerts R, Vandeweyer H, Penninckx F. Laparoscopic versus open liver resection of hepatic neoplasms: comparative analysis of short-term results. Surg Endosc. 2008;22(10):2208-2213.

48. Bryant R, Laurent A, Tayar C, Chergui D. Laparoscopic liver resection: understanding its role in current practice: the henri mondor hospital experience. Ann Surg. 2009;250(1):103-111.

49. Buell JF, Thomas MT, Rudich S, et al. Experience with more than 500 minimally invasive hepatic procedures. Ann Surg. 2008:248(3): 475-486.

50. Lesurtel M, Cherqui D, Laurent A, Tayar C, Fagniez PL. Laparoscopic versus open left lateral hepatic lobectomy: a case-control study. $J \mathrm{Am}$ Coll Surg. 2003;196(2):236-242.

51. Nguyen KT, Laurent A, Dagher I, et al. Minimally invasive liver resection for metastatic colorectal cancer: a multi-institutional, international report of safety, feasibility, and early outcomes. Ann Surg. 2009;250(5):842-848.

52. Simillis C, Constantinides VA, Tekkis PP, Darzi A, Lovegrove R, Jiao L, Antoniou A. Laparoscopic versus open hepatic resections for benign and malignant neoplasms: a meta-analysis. Surgery. 2007;141(2) 203-211.

53. Cherqui D, Laurent A, Mocellin N, et al. Liver resection for transplantable hepatocellular carcinoma: long-term survival and role of secondary liver transplantation. Ann Surg. 2009;250(5):738-746.

54. Sarpel U, Hefti MM, Wisnievsky JP, Roayaie S, Schwartz ME, Labow DM. Outcome for patients treated with laparoscopic versus open resection of hepatocellular carcinoma: case-matched analysis Ann Surg Oncol. 2009;16(6):1572-1577.

55. Nguyen KT, Gamblin TC, Geller DA. World review of laparoscopic liver resection: 2,804 patients. Ann Surg. 2009;250(5):831-841.

56. Wakabayashi G, Cherqui D, Geller DA, et al. Recommendations for laparoscopic liver resection: a report from the second international consensus conference held in Morioka. Ann Surg. 2015;261(4):619-629.

57. Nomi T, Fuks D, Kawaguchi Y, Mal F, Nakajima Y, Gayet B. Learning curve for laparoscopic major hepatectomy. Br J Surg. 2015;102(7):796-804.

58. Saif R, Jacob M, Robinson S, et al. Use of fibrin-based sealants and gelatin-matrix hemostats in laparoscopic liver surgery. Surg Laparosc Endosc Percutan Tech. 2011;21(3):131-141.

59. Llovet JM, Bru C, Bruix J. Prognosis of hepatocellular carcinoma: the BCLC staging classification. Semin Liver Dis. 1999;19(3):329-338.

60. Yau T, Tang VY, Yao TJ, Fan ST, Lo CM, Poon RT. Development of Hong Kong Liver Cancer staging system with treatment stratification for patients with hepatocellular carcinoma. Gastroenterology. 2014;146(7):1691-700.

61. Nishikawa H, Kita R, Kimura T, et al. Proposal of the performance status combined Japan integrated staging system in hepatocellular carcinoma complicated with cirrhosis. Int J Oncol. 2015;46(6):2371-2379.

62. Omata M, Lesmana LA, Tateishi R, et al. Asian Pacific association for the study of the liver consensus recommendations on hepatocellular carcinoma. Hepatol Int. 2010;4(2):439-474.

63. Kudo M, Izumi N, Kokudo N, et al. Management of hepatocellular carcinoma in Japan: consensus-based clinical practice guidelines proposed by the Japan society of hepatology (JSH) 2010 updated version. Dig Dis. 2011;29(3):339-365.

64. Chevret S, Trincet JC, Mathieu D, Rached AA, Beaugrand M, Chastang C. A new prognostic classification for predicting survival in patients with hepatocellular carcinoma. Groupe d'Etude et de Traitement du Carcinome Hepatocellulaire. J Hepatol. 1999;31(1):133-141.

65. Calvet X, Bruix J, Ginés P, Bru C, Solé M, Vilana R, Rodés J. Prognostic factors of hepatocellular carcinoma in the West: a multivariate analysis in 206 patients. Hepatology. 1990;12(4 Pt 1):753-760.

66. Breitenstein S, DeOliveira ML, Raptis DA, Slankamenac K, Kambakamba P, Nerl J, Clavien PA. Novel and simple preoperative score predicting complications after liver resection in noncirrhotic patients Ann Surg. 2010;252(5):726-734.

67. Chang CM, Yin WY, Su YC, et al. Preoperative risk score predicting 90-day mortality after liver resection in a population-based study. Medicine (Baltimore). 2014;93(12):e59.
68. Child CG, Turcotte JG. Surgery and portal hypertension. Major Probl Clin Surg. 1964;1:1-85.

69. Pugh RN, Murray-Lyon IM, Dawson JL, Pietroni MC, Williams R. Transection of the oesophagus for bleeding oesophageal varices. $\mathrm{Br}$ J Surg. 1973;60(8):646-649.

70. Caesar J, Shaldon S, Chiandussi L, Guevara L, Sherlock S. The use of indocyanine green in the measurement of hepatic blood flow and as a test of hepatic function. Clin Sci. 1961;21:43-57.

71. Faybik P, Hetz H. Plasma disappearance rate of indocyanine green in liver dysfunction. Transplant Proc. 2006;38(3):801-802.

72. Bernal W, Donaldson N, Wyncoll D,Wendon J. Blood lactate as an early predictor of outcome in paracetamol-induced acute liver failure: a cohort study. Lancet. 2002;359(9306):558-563.

73. Sathirakul K, Suzuki H, Yasuda K, Hanano M, Tagaya O, Horie T, Sugiyama Y. Kinetic analysis of hepatobiliary transport of organic anions in Eisai hyperbilirubinemic mutant rats. J Pharmacol Exp Ther. 1993;265(3):1301-1312.

74. Wissler EH. Identifying a long standing error in single-bolus determination of the hepatic extraction ratio for indocyanine green. Eur $J$ Appl Physiol. 2011;111(4):641-646.

75. Lam CM, Fan ST, Lo CM, Wong J. Major hepatectomy for hepatocellular carcinoma in patients with an unsatisfactory indocyanine green clearance test. Br J Surg. 1999;86(8):1012-1017.

76. Poon RT, Fan ST, Lo CM, et al. Improving perioperative outcome expands the role of hepatectomy in management of benign and malignant hepatobiliary diseases: analysis of 1,222 consecutive patients from a prospective database. Ann Surg. 2004;240(4):698-708; discussion 708-710.

77. Okochi O, Kaneko T, Sugimoto H, Inoue S, Takeda S, Nakao A. ICG pulse spectrophotometry for perioperative liver function in hepatectomy. J Surg Res. 2002;103(1):109-113.

78. Cheung TT, Chan SC, Chok SH, et al. Rapid measurement of indocyanine green retention by pulse spectrophotometry: a validation study in 70 patients with Child-pugh A cirrhosis before hepatectomy for hepatocellular carcinoma. Hepatobiliary Pancreat Dis Int 2012;11(3):267-271.

79. De Liguori Carino N, O'Reilly DA, Dajani K, Ghaneh P, Poston GJ, Wu AV. Perioperative use of the LiMON method for indocyanine green elimination measurement for the prediction and early detection of posthepatectomy liver failure. Eur J Surg Oncol. 2009;35(9):957-962.

80. Thomas MN, Weninger E, Angele M, et al. Intraoperative simulation of remnant liver function during anatomic liver resection with indocyanine green clearance (LiMON) measurements. HPB (Oxford). 2015;17(6):471-476.

81. Shirabe K, Shimada M, Gion T, Hasegawa H, Takenaka K, Utsunomiya T, Sugimachi K. Postoperative liver failure after major hepatic resection for hepatocellular carcinoma in the modern era with special reference to remnant liver volume. J Am Coll Surg. 1999;188(3):304-309.

82. Nakayama Y, Li Q, Katsuragawa S, et al. Automated hepatic volumetry for living related liver transplantation at multisection CT. Radiology. 2006;240(3):743-748.

83. Shoup M, Gonen M, D'Angelica M, et al. Volumetric analysis predicts hepatic dysfunction in patients undergoing major liver resection. J Gastrointest Surg. 2003;7(3):325-330.

84. Fan ST, Lo CM, Liu CL, Lam CM, Yuen WK, Yeung C, Wong J. Hepatectomy for hepatocellular carcinoma: toward zero hospital deaths. Ann Surg. 1999;229:322-330.

85. Chan SC, Liu CL, Lo CM, Lam BK, Lee EW, Wong Y, Fan ST. Estimating liver weight of adults by body weight and gender. World $J$ Gastroenterol. 2006;12(14):2217-2222.

86. Clavien PA, Emond J, Vauthey JN, Belghiti J, Chari RS, Strasberg SM Protection of the liver during hepatic surgery. J Gastrointest Surg. 2004;8(3):313-327.

87. Chan SC, Lo CM, Chok KS, et al. Validation of graft and standard liver size predictions in right liver living donor liver transplantation. Hepatol Int. 2011;5(4):913-917.

88. Vauthey JN, Abdalla EK, Doherty DA, et al. Body surface area and body weight predict total liver volume in Western adults. Liver Transpl. 2002;8(3):233-240. 
89. Urata K, Kawasaki S, Matsunami H, et al. Calculation of child and adult standard liver volume for liver transplantation. Hepatology. 1995;21(5):1317-1321.

90. de Graaf W, van Lienden KP, Dinant S, et al. Assessment of future remnant liver function using hepatobiliary scintigraphy in patients undergoing major liver resection. J Gastrointest Surg. 2010;14(2):369-378.

91. Hoekstra LT, de Graaf W, Nibourg GA, Heger M, Bennink RJ, Stieger B, van Gulik TM. Physiological and biochemical basis of clinical liver function tests: a review. Ann Surg. 2013;257(1):27-36.

92. de GraafW, Bennink RJ, Veteläinen R, van Gulik TM. Nuclear imaging techniques for the assessment of hepatic function in liver surgery and transplantation. J Nucl Med. 2010;51(5):742-752.

93. Krishnamurthy S, Krishnamurthy GT. Technetium-99m- iminodiacetic acid organic anions: review of biokinetics and clinical application in hepatology. Hepatology. 1989;9(1):139-153.

94. Ban D, Tanabe M, Ito H, et al. A novel difficulty scoring system for laparoscopic liver resection. J Hepatobiliary Pancreat Sci. 2014;21(10):745-753.

95. Kaneko H, Tsuchiya M, Otsuka Y, et al. Laparoscopy-assisted hepatectomy for giant hepatocellular carcinoma. Surg Laparosc Endosc Percutan Tech. 2008;18(1):127-131.

96. Cardinal JS, Reddy SK, Tsung A, Marsh JW, Geller DA. Laparoscopic major hepatectomy: pure laparoscopic approach versus hand-assisted technique. J Hepatobiliary Pancreat Sci. 2013;20(2):114-119.

97. Huang M, Lee W, Wang W, Wei PL, Chen RJ. Hand-assisted laparoscopic hepatectomy for solid tumor in the posterior portion of the right lobe: initial experience. Ann Surg. 2003;238(5):674-679.

98. Makuuchi M, Takayasu K, Takuma T, Yamazaki S, Hasegawa H, Nishiura S, Shimamura Y. Preoperative transcatheter embolization of the portal venous branch for patients receiving extended lobectomy due to the bile duct carcinoma. J Jpn Soc Clin Surg. 1984;45(12): 14-20.

99. Makuuchi M, Thai BL, Takayasu K, et al. Preoperative portal embolization to increase safety of major hepatectomy for hilar bile duct carcinoma: a preliminary report. Surgery. 1990;107(5):521-527.

100. Azoulay D, Castaing D, Krissat J, et al. Percutaneous portal vein embolization increases the feasibility and safety of major liver resection for hepatocellular carcinoma in injured liver. Ann Surg. 2000;232(5): 665-672.

101. Tanaka H, Hirohashi K, Kubo S, Shuto T, Higaki I, Kinoshita H. Preoperative portal vein embolization improves prognosis after right hepatectomy for hepatocellular carcinoma in patients with impaired hepatic function. Br J Surg. 2000;87(7):879-882.

102. Palavecino M, Chun YS, Madoff DC, et al. Major hepatic resection for hepatocellular carcinoma with or without portal vein embolization: perioperative outcome and survival. Surgery. 2009;145(4):399-405.

103. Ogata S, Belghiti J, Farges O, Varma D, Sibert A, Vilgrain V. Sequential arterial and portal vein embolizations before right hepatectomy in patients with cirrhosis and hepatocellular carcinoma. Br J Surg. 2006;93(9):1091-1098.

104. Hayashi S, Baba Y, Ueno K, et al. Acceleration of primary liver tumor growth rate in embolized hepatic lobe after portal vein embolization. Acta Radiol. 2007;48(7):721-727.

105. Schnitzbauer AA, Lang SA, Goessmann H, et al. Right portal vein ligation combined with in situ splitting induces rapid left lateral liver lobe hypertrophy enabling 2-staged extended right hepatic resection in small-for-size settings. Ann Surg. 2012;255(3):405-414.

106. Schadde E, Ardiles V, Robles-Campos R, et al. Early survival and safety of ALPPS: first report of the international ALPPS registry. Ann Surg. 2014;260(5):829-836; discussion 836-838.

107. Schadde E, Ardiles V, Slankamenac K, et al. ALPPS offers a better chance of complete resection in patients with primarily unresectable liver tumors compared with conventional-staged hepatectomies: results of a multicenter analysis. World J Surg. 2014;38(6):1510-1519.

108. Oldhafer KJ, Donati M, Jenner RM, Stang A, Stavrou GA. ALPPS for patients with colorectal liver metastases: effective liver hypertrophy, but early tumor recurrence. World J Surg. 2014;38(6):1504-1509.
109. Chearanai O, Plengvanit U, Asavanich C, Damrongsak D, Sindhvananda $\mathrm{K}$, Boonyapisit S. Spontaneous rupture of primary hepatoma: report of 63 cases with particular reference to the pathogenesis and rationale treatment by hepatic artery ligation. Cancer. 1983;51(8):1532-1536.

110. Liu CL, Fan ST, Lo CM, Tso WK, Poon RT, Lam CM, Wong J. Management of spontaneous rupture of hepatocellular carcinoma: single-center experience. J Clin Oncol. 2001;19(17):3725-3732.

111. Kew MC, Dos Santos HA, Sherlock S. Diagnosis of primary cancer of the liver. Br Med J. 1971;4(5784):408-411.

112. Lee HS, Choi GH, Kang DR, et al. Impact of spontaneous hepatocellular carcinoma rupture on recurrence pattern and long-term surgical outcomes after partial hepatectomy. World J Surg. 2014;38(8):2070-2078.

113. Yang T, Sun YF, Zhang J, et al. Partial hepatectomy for ruptured hepatocellular carcinoma. Br J Surg. 2013;100(8):1071-1079.

114. Fong Y, Sun RL, Jarnagin W, Blumgart LH. An analysis of 412 cases of hepatocellular carcinoma at a Western center. Ann Surg. 1999;229(6):790-799; discussion 799-800.

115. Llovet JM, Bustamante J, Castells A, et al. Natural history of untreated nonsurgical hepatocellular carcinoma: rationale for the design and evaluation of therapeutic trials. Hepatology. 1999;29(1):62-67.

116. Pawlik TM, Poon RT, Abdalla EK, et al. Hepatectomy for hepatocellular carcinoma with major portal or hepatic vein invasion: results of a multicenter study. Surgery. 2005;137(4):403-410.

117. Chen XP, Qiu FZ, Wu ZD, et al. Effects of location and extension of portal vein tumor thrombus on long-term outcomes of surgical treatment for hepatocellular carcinoma. Ann Surg Oncol. 2006;13(7):940-946.

118. Wu CC, Hsieh SR, Chen JT, et al. An appraisal of liver and portal vein resection for hepatocellular carcinoma with tumor thrombi extending to portal bifurcation. Arch Surg. 2000;135(11):1273-1279.

119. Ohkubo T, Yamamoto J, Sugawara Y, Shimada K, Yamasaki S, Makuuchi M, Kosuge T. Surgical results for hepatocellular carcinoma with macroscopic portal vein tumor thrombosis. J Am Coll Surg. 2000;191(6):657-660

120. Yamamoto Y, Ikoma H, Morimura R, et al. Post-hepatectomy survival in advanced hepatocellular carcinoma with portal vein tumor thrombosis. World J Gastroenterol. 2015;21(1):246-253.

121. Chok KS, Cheung TT, Chan SC, Poon RT, Fan ST, Lo CM. Surgical outcomes in hepatocellular carcinoma patients with portal vein tumor thrombosis. World J Surg. 2014;38(2):490-496.

122. Inoue $\mathrm{Y}$, Hasegawa $\mathrm{K}$, Ishizawa $\mathrm{T}$, et al. Is there any difference in survival according to the portal tumour thrombectomy method in patients with hepatocellular carcinoma? Surgery. 2009;145(1):9-19.

123. Ban D, Shimada K, Yamamoto Y, Nara S, Esaki M, Sakamoto Y, Kosuge T. Efficacy of a hepatectomy and a tumor thrombectomy for hepatocellular carcinoma with tumor thrombus extending to the main portal vein. J Gastrointest Surg. 2009;13(11):1921-1928.

124. Kondo M, Morimoto M, Numata K, Nozaki A, Tanaka K. Hepatic arterial infusion therapy with a fine powder formulation of cisplatin for advanced hepatocellular carcinoma with portal vein tumor thrombosis. Jpn J Clin Oncol. 2011;41(1):69-75.

125. Lai E, Lau W. Hepatocellular carcinoma presenting with obstruc- tive jaundice. ANZ J Surg. 2006;76(7):631-636.

126. Meng K, Dong M, Zhang W, Huang Q. Clinical characteristics and surgical prognosis of hepatocellular carcinoma with bile duct invasion. Gastroenterol Res Pract. 2014;2014:604971.

127. Lin T, Chen K, Chen Y, Lin W, Wang T, Sung J. Icteric type hepatoma. Med Chir Dig. 1975;4(5-6):267-270.

128. Yu X, Xu L, Liu C, Zhang R, Wang J. Clinicopathological characteristics of 20 cases of hepatocellular carcinoma with bile duct tumor thrombi. Dig Dis Sci. 2011;56(1):252-259.

129. Ikenaga N, Chijiiwa K, Otani K, Ohuchida J, Uchiyama S, Kondo K. Clinicopathologic characteristics of hepatocellular carcinoma with bile duct invasion. J Gastrointest Surg. 2009;13(3):492-497.

130. Yeh C, Jan Y, Lee W, Chen MF. Hepatic resection for hepatocellular carcinoma with obstructive jaundice due to biliary tumor thrombi. World J Surg. 2004;28(5):471-475. 
131. Wong TC, Cheung TT, Chok KS, et al. Outcomes of hepatocellular carcinoma with bile duct tumor thrombus. HPB (Oxford). 2015;17(5):401-408.

132. Ueda M, Takeuchi T, Takayasu T, et al. Classification and surgical treatment of hepatocellular carci- noma (HCC) with bile duct thrombi. Hepatogastroenterology. 1994;41(4):349-354.

133. Chok KS, Cheung TT, Chan AC, Dai WC, Chan SC, Lo CM. Liver resection for de novo hepatocellular carcinoma complicated by pyogenic liver abscess: a clinical challenge. World J Surg. 2016;40(2):412-418.

134. Okuda K, Kondo Y, Nakano M, et al. Hepatocellular carcinoma presenting with Pyrexia and Leukocytosis: report of five cases. Hepatology. 1991;13(4):695-700.

135. Li C, Li G, Miao R, et al. Primary liver cancer presenting as pyogenic liver abscess: characteristics, diagnosis, and manage- ment. J Surg Oncol. 2012;105(7):687-691.

136. DuBay D, Sandroussi C, Sandhu L, et al. Liver transplantation for advanced hepatocellular carcinoma using poor tumor differentiation on biopsy as an exclusion criterion. Ann Surg. 2011;253(1):166-172.
137. Majno PE, Sarasin FP, Mentha G, Hadengue A. Primary liver resection and salvage transplantation or primary liver transplantation in patients with single, small hepatocellular carcinoma and preserved liver function: an outcome-oriented decision analysis. Hepatology. 2000;31(4): 899-906.

138. Belghiti J, Cortes A, Abdalla EK, et al. Resection prior to liver transplantation for hepatocellular carcinoma. Ann Surg. 2003;238(6): 885-892.

139. Adam R, Azoulay D, Castaing D, et al. Liver resection as a bridge to transplantation for hepatocellular carcinoma on cirrhosis: a reasonable strategy? Ann Surg. 2003;238(4):508-518.

140. Poon RT, Fan ST, Lo CM, Liu CL, Wong J. Difference in tumor invasiveness in cirrhotic patients with hepatocellular carcinoma fulfilling the Milan criteria treated by resection and transplantation: impact on long-term survival. Ann Surg. 2007;245(1):51-58.

141. Chan AC, Chan SC, Chok KH, et al. Treatment strategy for recurrent hepatocellular carcinoma: salvage transplantation, repeated resection or repeated radiofrequency ablation? Liver Transpl. 2013;19(4): $411-419$.
Journal of Hepatocellular Carcinoma

\section{Publish your work in this journal}

The Journal of Hepatocellular Carcinoma is an international, peerreviewed, open access journal that offers a platform for the dissemination and study of clinical, translational and basic research findings in this rapidly developing field. Development in areas including, but not limited to, epidemiology, vaccination, hepatitis therapy, pathology and

\section{Dovepress}

molecular tumor classification and prognostication are all considered for publication. The manuscript management system is completely online and includes a very quick and fair peer-review system, which is all easy to use. Visit http://www.dovepress.com/testimonials.php to read real quotes from published authors. 